\title{
Konsepsi Pengembangan Kemampuan Kepemimpinan Pendidikan Islam
}

\author{
Zaenal Arifin $^{1}$ \& Sulistyorini ${ }^{2}$ \\ ${ }^{1}$ Institut Agama Islam Tribakti Kediri \\ Email: zae.may13@gmail.com \\ ${ }^{2}$ Institut Agama Islam Negeri Tulung Agung \\ Email: sulistyorini12@yahoo.com
}

\begin{abstract}
:
Writing this article aims to explain the conception of leadership and the development of leadership abilities in both formal and non-formal Islamic education institutions. Leaders are an important element in the process of managing educational institutions, therefore leaders in Islamic educational institutions are expected to continue to be able to develop their abilities. This study uses the literature method with content analysis as the analysis technique. To develop their abilities, at least a leader must know the potential associated with the leader's abilities and know-how to develop them.
\end{abstract}

Keywords: Leadership Conception, Development of Leadership Capabilities, Islamic Education Leadership

\begin{abstract}
Abstrak
Penulisan artikel ini bertujuan untuk menjelaskan konsepsi kepemimpinan dan pengembangan kemampuan pemimpin pada lembaga pendidikan Islam baik formal maupun non formal. Pemimpin merupakan unsur penting dalam proses pengelolaan lembaga pendidikan, untuk itu pemimpin dalam lembaga pendidikan Islam diharapkan dapat terus mampu mengembangkan kemampuannya. Kajian ini menggunakan metode kepustakaan dengan konten analisis sebagai teknik analisisnya. Untuk mengembangkan kemampuanya, setidaknya seorang pemimpin harus mengetahui potensi yang berkaitan dengan kemampuan pemimpin serta mengetahui cara bagaimana mengembangkannya.
\end{abstract}

Kata Kunci: Kepemimpinan, Pengembangan, Pendidikan Islam 


\section{Pendahuluan}

Pemimpin merupakan (Abuddin Nata, 2012, p. 7) unsur terpenting dalam proses manajemen secara umum maupun manajemen dalam konteks pendidikan Islam. Baik dan tidaknya hasil yang dicapai sebuah organisasi ditentukan oleh kemampuan seorang pemimpin dalam menjalankan tugasnya. Pemimpin sering dikonotasikan dengan manajer, tetapi kepemimpinan tidak sama dengan manajerial (proses manajemen), dimana kepemimpinan merupakan proses mempengaruhi kelompok untuk melaksanakan tugas dalam rangka mencapai tujuan bersama (Gary Yukl, 1998, p. 2). Semantara manajerial merupakan proses melaksanakan fungsi manajemen yang meliputi: planning, organizing, leading, controlling (Abuddin Nata, 2012).

Kepemimpinan pendidikan merupakan strategi untuk menciptakan perubahan institusi pendidikan kearah lebih baik, sehingga kemampuan seorang pemimpin sangat signifikan untuk terus ditingkatkan dalam rangka mencapai tujuan pendidikan yang ideal (Hidayati, 2016).

Individu sebagai pemimpin yang eksistensinya bertanggung jawab terhadap lembaga pendidikan Islam, pengembangan kepemimpinan (leadership development) yang keberadaannya dapat diartikan sebagai perluasan kapasitas seseorang dalam menjalankan suatu manajemen untuk mencapai sesuatu yang lebih efektif dalam peran dan proses kepemimpinan (Syadzili, 2018). Untuk itu, seorang pemimpin dituntut untuk mengembangkan kemampuannya dalam memimpin lembaga pendidikan Islam.

Kepemimpinan yang efektif juga kurang tentang belajar "teknik" dan lebih banyak tentang membangun karakter. Pemimpin hari ini dan masa depan akan difokuskan pada bagaimana menjadi dan bagaimana mengembangkan kualitas, karakter, pola pikir, nilai-nilai, prinsip, dan keberanian. Pemimpin yang kuat akan visioner, dengan keyakinan bahwa mereka dapat dan harus membentuk masa depan (David R. Kolzow, 2014, p. 310).

\section{Metode}

Penelitian ini menggunakan metode penelitian kualitatif dengan pendekatan kepustakaan. Data dari penelitian ini merupakan data kepustakaan yang digali melalui penelusuran di beberapa Jurnal online. Untuk menganalisisnya penulis menggunakan teknik konten analisis. Teknik ini digunakan untuk menganalisis data yang telah 
terkumpulkan dengan cara mencari mengelaborasi masing-masing data kemudian mengambil benang merah untuk dibuat sebuah kesimpulan yang berupa konsepsi.

\section{Hasil Penelitian atau Temuan}

\section{Konsepsi Dasar Kepemimpinan Pendidikan}

Sebelum membahas mengenai konsep kepemimpinan dalam konteks pendidikan, terlebih dahulu penulis mengulas beberapa konsepsi menganai kepemimpinan. Hal ini penting agar kita dapat memposisikan konsep kepemimpinan secara tepat, karena konsepsi kepemimpinan mengalami perubahan sesuai dengan konteksnya. Konsep kepemimpinan sangat tidak berbentuk dan sulit dipahami, sulit dalam arti mendefinisikan konsep tersebut untuk memuaskan semua kalangan. Namun, pada kalangan akademisi memiliki kesepakatan bahwa kepemimpinan sangan situasional dan kontekstual, bahwa pemimpin yang berhasil dalam satu konteks tidak perlu berhasil pada konteks lain, atau berhasil memimpin dalam suatu kelompok belum tentu jika memimpin kelompok lainnya, atau berhasil ada satu waktu belum tentu dapat berhasil pada waktu yang lainnya. Selain itu, sebagian besar penulis setuju bahwa kepemimpinan dapat diajarkan dan dipelajari, meskipun yang lain percaya bahwa bakat kepemimpinan tertentu adalah bawaan sejak lahir (Muna \& Zennie, 2010, p. 9).

Kata kepemimpinan memiliki akar kata pemimpin yang berarti orang yang memiliki power atau kuasa untuk mempengaruhi orang lain yang ada dibawah kuasanya agar melakukan sesuatu dalam rangka mencapai tujuan. Kepemimpinan memiliki arti yang berbedabeda jika didefinisikan oleh orang yang berbeda pula (Arifin, 2016). Para peneliti mendefinisikan kepemimpinan hampir selalu didasarkan pada perspektif individual dan fenomena yang menarik perhatian mereka (Arifin, 2016). Kepemimpinan didefinisikan sebagai ciri-ciri individual, perilaku, pola interaksi, hubungan peran, pengaruh pada kelompok, dan tempat pada posisi administratif. Namun, secara tegas para peneliti sepakat bahwa unsur penting dari kempemimpinan adalah sebuah proses ketimbang kepemimpinan sebagai individu.

Kepemimpinan sebagai sebuah proses merupakan kepemimpinan yang disamakan dengan proses produksi. Proses tersebut terdiri dari masukan, proses, dan keluaran (Wirawan, 2014, p. 7). Untuk lebih jelasnya lihat tabel di bawah ini: 
Tabel. 1. Kepemimpinan sebagai sebuah proses

\begin{tabular}{|c|c|c|}
\hline Masukan & Proses & Keluaran \\
\hline $\begin{array}{l}\text { 1. Pemimpin } \\
\text { 2. Pengikut } \\
\text { 3. Visi \& Misi } \\
\text { 4. Budaya } \\
\text { Organisasi } \\
\text { 5. Kekuasaan } \\
\text { 6. Sumber-sumber } \\
\text { 7. Lingkungan } \\
\text { internal dan } \\
\text { Eksternal }\end{array}$ & $\begin{array}{l}\text { 1. Interaksi sosial } \\
\text { pemimpin-pengikut } \\
\text { 2. Pemimpin- } \\
\text { pengikut saling } \\
\text { mempengaruhi } \\
\text { 3. Proses terjadinya } \\
\text { perubahan } \\
\text { 4. Pemimpin } \\
\text { memberdayakan } \\
\text { pengikut } \\
\text { 5. Upaya } \\
\text { merealisasikan misi } \\
\text { 6. Manajemen konflik } \\
\text { 7. Memanajemeni } \\
\text { kinerja }\end{array}$ & $\begin{array}{l}\text { 1. Pengikut } \\
\text { terpengaruhi/tidak } \\
\text { 2. Terjadi } \\
\text { perubahan/tidak } \\
\text { 3. Visi tercapai/tidak } \\
\text { 4. Kehidupan } \\
\text { anggota sosial } \\
\text { lebih baik/tidak }\end{array}$ \\
\hline
\end{tabular}

Dalam konteks pendidikan, kepemimpinan menjadi faktor penentu keberhasilan pencapaian tujuan pendidikan (Sutarto, 2006, p. 15). Meskipun sebenarnya banyak faktor yang mempengaruhi tingkat keberhasilan institusi pendidikan, namum kepemimpinan menjadi faktor utama. Sebagaimana Stephen Robin yang medefinisikan kepemimpinan sebagai sebuah proses mempengaruhi kelompok untuk mencapai tujuan (Robbins, 2001, p. 365), sehingga kepemimpinan lebih menekankan pada aspek sejauh mana pemimpin mampu mempengaruhi kelompoknya untuk bersama-sama mencapai tujuan.

Istilah kepemimpinan dalam konteks kepemimpinan pendidikan memiliki banyak varian istilah, diantaranya, educational leadership, educational administration, educational management, school leadership, dan instructional leadership. Meskipun demikian, apapun istilahnya, semuanya memiliki pengertian dan cakupan yang sama (Wirawan, 2014, p. 533). Kepemimpinan pendidikan adalah proses mempengaruhi para peserta didik dan para pemangku kepentingan pendidikan serta menciptakan sinergi untuk mencapai tujuan pendidikan. Kepemimpinan pendidikan merupakan sebuah sistem, dan berbagai pakar dan asosiasi pendidikan telah berbagai model kepemimpinan pendidikan. Seperti model yang dikembangkan oleh 
Asosiasi Kepala Sekolah di Australia yang merumuskan model kepemimpinan "Apapde's Educational Leadership Model (AELM)" yang digambarkan seperti gambar dibawah ini.

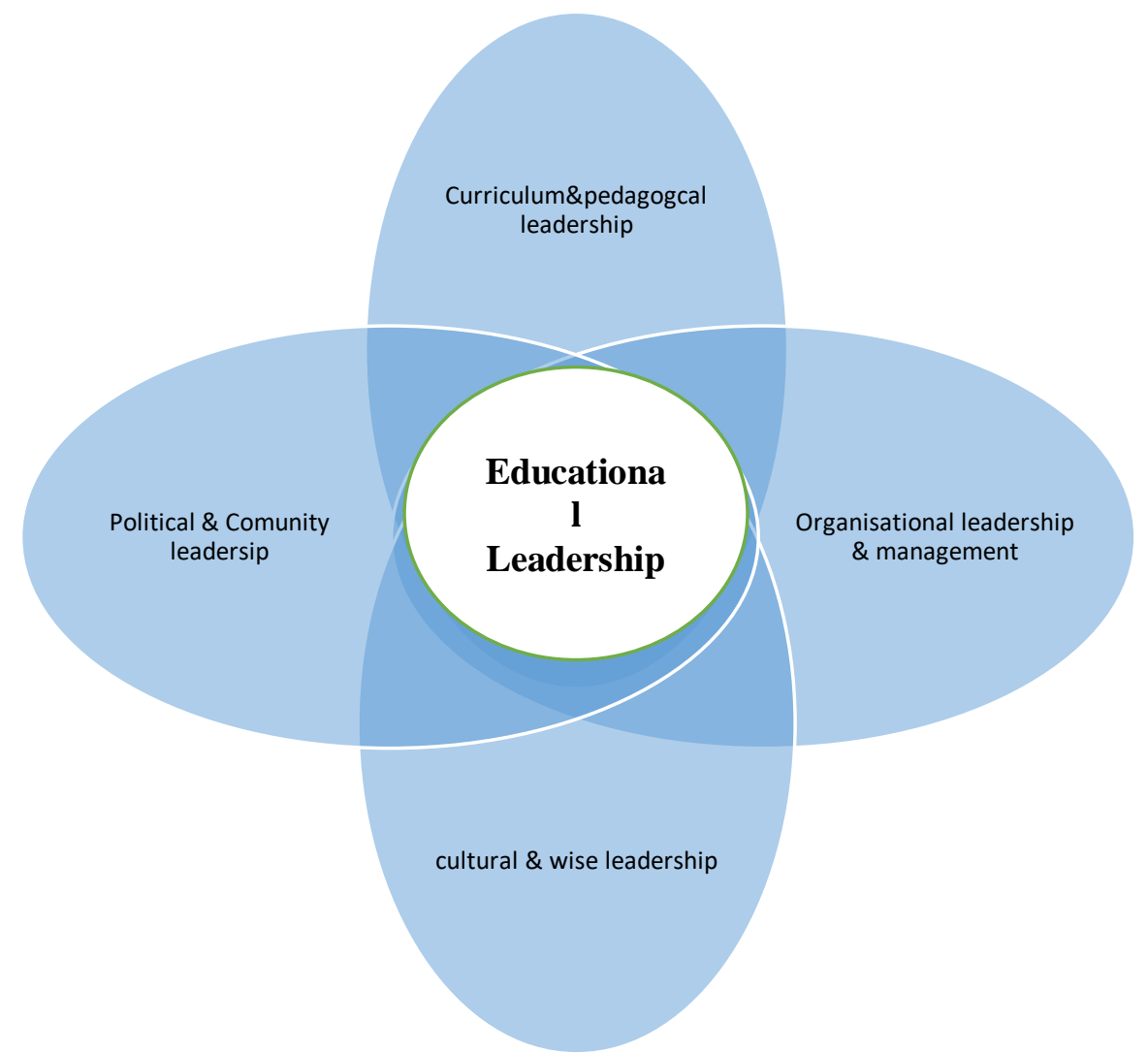

Dari gambar diatas, dapat dipahami bahwa pertama, seorang pemimpin pendidikan perlu menguasai teori dan aplikasi kurikulum dan pedagogi untuk melaksanakan proses pendidikan dan pembelajaran. Kedua, seorang pemimpin pendidikan harus mempunyai visi dan mampu mengembangkan secara komprehensif suatu tujuan bersama kearah pendidikan di kemudian hari. Ketiga, seorang pemimpin pendidikan harus mampu memahami dan mengakui nilai-nilai budaya masyarakat, bertindak secara etis, dan merefleksikan kepercayaan. Keempat, seorang pemimpin institusi pendidikan harus mempunyai kemampuan bernegosiasi dengan sistem, dan berbagai sektor, orang tua, para guru, dan anggota masyarakat kearah kesejahteraan sekolah. Kelima, tujuan dari 
kepemimpinan pendidikan adalah menciptakan sinergi untuk mengoptimalkan proses pembelejaran dalam rangka mencapai tujuan pembelajaran.

Stephen R. Covey dalam bukunya menyebutkan setidaknya terdapat empat fungsi kepemimpinan, yaitu: modelling-pathfindingaligning-empowering. Fungsi modelling diartikan sebagai fungsi pemberi contoh yang baik, seorang pemimpin harus memberikan contoh yang baik kepada bawahannya. Fungsi modelling merupakan sentral dari teori kepemimpinan. Pathfinding menentukan arah yaitu, peran seorang pemimpin dalam menentukan visi, misi dan strategi kemudian membaginya dengan tim yang dipimpinnya. Penting sekali dalam hal ini memastikan peran kepemimpinan sehingga tujuan organisasi di ketahui hingga sampai ke semua level. Pathfinding diartikan sebagai fungsi perintis, fungsi ini mencakup bagaimana usaha seorang pemimpin dan memenuhi kebutuhan utama para stakeholder dan kearah mana visi dan misi organisasi diarahkan.

Fungsi aligning atau penyelaras dimaksudkan atau berkenaan dengan bagaimanakah seorang pemimpin dapat menyelaraskan seluruh sistem dalam organisasi, supaya dapat saling sinergis dalam bekerja (Indah Kusuma Dewi, 2019). Seorang pemimpin dalam lembaga pendidikan Islam juga dituntut mengetahui bagian-bagian system organisasi, sebagai pemimpin tidak hanya berdiam diri di ruangan semata, namun juga turun langsung kepada para pegawainya dengan tujuan memahami keseluruhan system yang ada dalam organisasi atau lembaganya. Pemimpin tidak hanya menerima laporan saja, melainkan juga melihat dan merasakan sendiri bagaimana kinerja pegawainya berjalan.

Fungsi empowering atau pemberdayaan berkenaan dengan bagaimana usaha menejemen/pemimpin untuk membangun dan mengembangkan lingkungn organisasi agar individu yang ada di dalamnya dapat menunjukkan performa terbaik dan memiliki komitmen yang kuat. Fungsi ini dapat dijalankan dengan cara memberikan motivasi dan semangat kerja yang baik, implementasi nilai keadilan agar menumbuhkan komitmen yang kuat, mendelegasikan individu sesuai dengan tugas dan wewenangnya agar menumbuhkan rasa tanggung jawab, serta menyesuaikan tugas dan wewenang individu dengan kualifikasi dan potensinya.

Pemimpin institusi pendidikan berfungsi sebagai manajer, pendidik, pengawas, dan motivator bagi guru-guru dalam proses 
kependidikan melalui pembelajaran dan latihan (Nasution, 2016). Fungsi manajer adalah sebagai pelaku manajerial mulai dari planning, organizing, leading, controlling, fungsi pendidik merupakan fungsi pemimpin institusi pendidikan terutama ketika berinteraksi dengan peserta didik, namun fungsi ini juga harus tetap dijalankan ketika berinteraksi dengan tenaga pendidik maupun tenaga kependidikan.

\section{Kemampuan Pemimpin dan Efektifitas Kepemimpinan}

Asumsi mengenai kepemimpinan dan siapa yang mempraktekkannya selalu berubah-ubah setiap tahunnya, pada saat tertentu keahlian kepemimpinan merupakan bakat bawaan dari sejak lahir, sebagaimana teori kepemimpinan Great Man, dimana teori ini memandang bahwa keahlian kepemimpinan terdapat pada individu karena adanya warisan dan keberuntungan. Pada saat lainnya, kepemimpinan diperoleh individu karena adanya peristiwa besar yang mampu membuat individu tersebut menjadi pemimpin meskipun bukan berasal dari keluarga pemimpin, sebagaimana teori Big Bang (Arifin, 2016).

Kemampuan pemimpin atau leadership skill merupakan faktor yang sangat berpengaruh terhadap keberhasilan seorang pemimpin menggerakkan anggotanya untuk mencapai tujuan. Berkenaan dengan hal tersebut, jika ditinjau dari jenisnya, kemampuan pemimpin secara garis besar terbagi kedalam dua jenis, yaitu technical skill dan soft skill. Technical skill atau keterampilan teknis berkaitan dengan kemampuan pemimpin yang sesuai dengan bidangnya, sementara soft skill berkaitan dengan kemampuan seorang pemimpin dalam mengendalikan situasi dan kondisi serta kemampuan menempatkan dirinya dengan tepat pada lingkungan pekerjaannya atau dikenal dengan kemampuan interpersonal. Kemampuan ini meliputi; kemampuan negosiasi, kemampuan diplomasi, kemampuan adaptasi, kemampuan membangun semangat, dan kemampuan menjaga hubungan baik dengan berbagai pilihan. Soft skill memiliki peran penting dalam sebuah kepemimpinan, bahwa soft skill memiliki peran sebesar 90\% dari sebuah keberhasilan kepemimpinan (Neff et al., 2001).

Berbeda halnya dengan Robert L. Kaltz yang membagi kemapuan pemimpin menjadi tiga kemampuan, yaitu: technical skill, human relations skill, dan conceptual or design skill (Afshari Mostafa et al., 2012; Seyedinejat et al., 2014). Pembagian ini didasarkan 
pada level kepemimpinan dalam manajemen, karena setiap level kepemimpinan dalam sebuah manajemen memiliki fungsi yang berbeda. Keterampilan konseptual adalah kemampuan untuk memvisualisasikan (melihat) organisasi secara keseluruhan. Ini termasuk keterampilan Analitis, Kreatif dan Inisiatif. Menurut Katz, keterampilan konseptual sebagian besar diperlukan oleh manajemen tingkat atas karena mereka menghabiskan lebih banyak waktu dalam perencanaan, pengorganisasian, dan penyelesaian masalah. Human relations skill juga disebut keterampilan interpersonal. Ini adalah kemampuan untuk bekerja dengan orang. Sementara keterampilan teknis adalah kemampuan untuk melakukan pekerjaan yang diberikan. Keterampilan teknis membantu para manajer untuk menggunakan berbagai mesin dan alat.

Kaltz membagi pemimpin dalam tiga level, yaitu; top leader, midle lider, dan lower leader, Menurut Kaltz semakin tinggi level pemimpin semakin rendah kemampuan teknis yang harus dimiliki seorang pemimpin dan semakin tinggi kemampuan konseptual yang harus dimiliki. Demikian sebalikny, semakin rendah level kepemimpinan semakin tinggi kemampuan teknis yang harus dimiliki dan semakin rendah kemampuan konseptual yang dibutuhkan. Berikut gambaran Kaltz:

\section{KETERAMPILAN MANAJEMEN (MANAGEMENT SKILLS)}

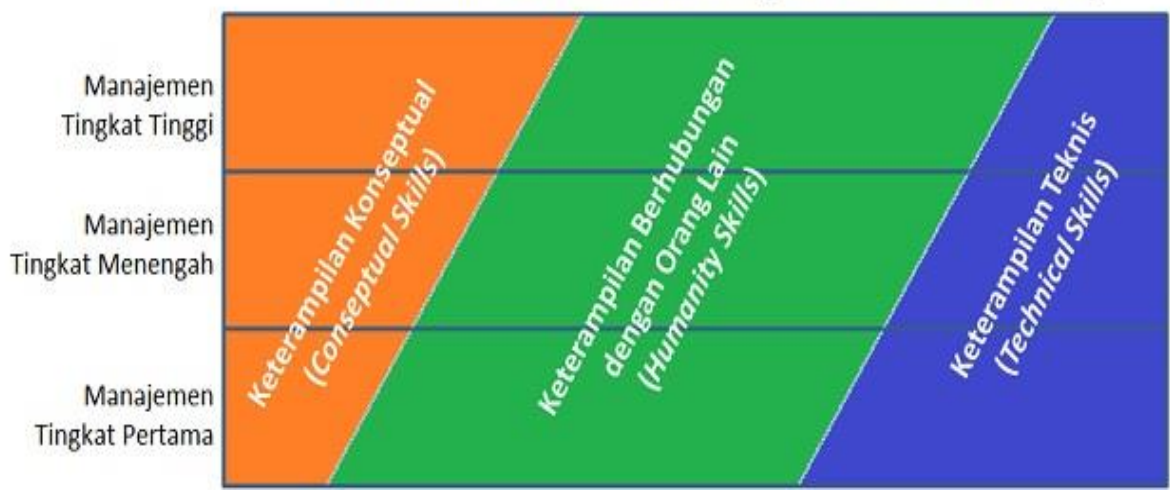

Selain kemampuan atau skill yang dimiliki individu, gender juga berpengaruh terhadap efektifitas sebuah kepemimpinan. Sebuah studi menyatakan bahwa gender memiliki korelasi yang signifikan terhadap efektifitas kepemimpinan dalam hal hubungan (informasi keuangan, tata kelola perusahaan, dan pengalaman) dan pengambilan 
keputusan investasi (Romy Faisal Mustofa et al., 2019), perempuan memiliki kemampuan skor diatas laki-laki dalam kemampuan administrasi dan teknis (Ghanem \& Abu Awwad, 2019).

Dari paparan diatas, kemampuan pemimpin yang dapat dikembangkan secara signifikan meliputi: kemampuan kemempuan menciptakan visi, kemampuan, komunikasi, kemampuan memberikan motivasi, kemampuan mengarahkan, kemampuan mengambil keputusan, kemampuan membina.

\section{Vision}

Seorang pemimpin memiliki visi, seorang pemimpin yang baik memiliki visi yang jelas dan seorang pemimpin yang hebat memiliki visi yang terjalin dengan rencana aksi. Karenanya, kualitas sentral dari semua pemimpin ini ada di bagian atas dan tengah model. Para pemimpin membangun visi untuk masa depan dan menetapkan strategi untuk sampai ke sana; mereka menyebabkan perubahan. Pemimpin dapat melihat masalah yang perlu diperbaiki atau tujuan yang harus dicapai. Mungkin sesuatu yang tidak dilihat orang lain atau hanya sesuatu yang tidak ingin ditangani orang lain.

\section{Passion}

Pemimpin yang baik fokus dan hanya mengarahkan melalui visi mereka. Mereka tahu bahwa tidak cukup hanya memiliki visi. Banyak orang melihat hal-hal yang harus dilakukan, hal-hal yang harus diperbaiki dan langkah maju yang dapat diambil. Apa yang membawa pengaruh emosional untuk melakukan serangkaian tindakan untuk menemani tujuan? Ini adalah hasrat untuk ide, rasa dorongan batin dan rasa komitmen. Para pemimpin bergerak maju di tengah segala rintangan; meskipun orang mengatakan itu tidak bisa dilakukan; bahwa itu terlalu mahal; yang kami coba sebelumnya, atau selusin alasan lainnya. Seorang pemimpin sejati bertahan dan bergerak maju.

\section{Influence}

Kemampuan untuk memengaruhi orang lain dan menyebabkan mereka bergerak ke arah tertentu adalah keterampilan yang sangat penting dalam kepemimpinan. Faktanya, kepemimpinan sering didefinisikan sebagai kemampuan untuk membujuk atau memengaruhi orang lain untuk melakukan sesuatu yang mungkin tidak akan mereka lakukan tanpa bujukan seorang pemimpin. Ada yang mengatakan bahwa seorang pemimpin harus dapat memotivasi setiap orang untuk berkontribusi. Untuk memimpin dan menetapkan arah, seorang 
pemimpin perlu tampil percaya diri sebagai pribadi dan dalam peran kepemimpinan. Orang seperti itu menginspirasi kepercayaan pada orang lain dan menarik kepercayaan dan upaya terbaik dari tim untuk menyelesaikan tugas dengan baik. Seorang pemimpin yang menyampaikan kepatuhan pada tujuan yang diusulkan mengilhami upaya terbaik dari anggota tim.

\section{Communication}

Keluhan utama anggota organisasi di hampir setiap organisasi, baik besar maupun kecil, adalah 'kurangnya komunikasi'. Komunikasi, dalam konteks kepemimpinan, mengacu pada komunikasi interpersonal antara pemimpin dan pengikut dan keseluruhan arus informasi yang diperlukan di seluruh organisasi. Komunikasi yang efektif lebih dari sekadar mampu berbicara dan menulis. Komunikasi seorang pemimpin harus menggerakkan orang untuk bekerja menuju tujuan yang telah dipilih pemimpin. Oleh karena itu, para pemimpin perlu belajar untuk menjadi mahir dalam komunikasi yang menginformasikan dan mencari informasi (memberi mereka suara) dan komunikasi yang menghubungkan antarpribadi dengan orang lain. Dengarkan karyawan dan hargai mereka dengan tulus. Menggunakan bahasa yang kuat dan positif dalam interaksi dengan orang lain. Kata 'tolong' dan 'terima kasih' dan 'Anda melakukan pekerjaan dengan baik'. Pengakuan yang kuat dan positif membuat orang merasa penting. Pengakuan yang kuat dan positif mendorong anggota untuk berkontribusi lebih banyak dari pekerjaan yang sama di masa depan. Para pemimpin yang baik mendengarkan orang-orang di organisasi mereka. Tidaklah cukup bagi para pemimpin untuk berbicara kepada orang-orang tentang hasrat mereka; mereka harus membiarkan ide dan pemikiran anggota meresap dan membantu membentuk tujuan dan rencana tindakan.

Komunikasi adalah ikatan yang mengikat suatu organisasi bersama. Alat ini akan membantu pemimpin untuk berkomunikasi secara terbuka dengan bawahan, dan dengan demikian berkontribusi pada pengembangan organisasi secara keseluruhan. Praktik komunikasi yang efektif membuat perbedaan sikap karyawan terhadap organisasi. Berikut manfaat dari komunikasi yang baik(Hiebert \& Klatt, 2001, p. 239):

1. Meningkatan komitmen dari karyawan, karena mereka memahami tujuan organisasi, dan peran mereka sendiri dalam mencapai tujuan tersebut; 
2. Kerja sama yang lebih besar di seluruh unit bisnis organisasi dan kelompok kerja;

3. Penghapusan rumor dan asumsi yang salah yang menciptakan kesalahpahaman atau merusak moral karyawan;

4. Karyawan merasa diakui dan termotivasi untuk mengambil inisiatif, seperti menawarkan ide-ide baru.

\section{Integrity}

kepemimpinan adalah melakukan apa yang benar ketika tidak ada yang melihat. Integritas berarti kejujuran dan lebih banyak lagi. Ini mengacu pada memiliki prinsip-prinsip panduan internal yang kuat yang tidak dapat dikompromikan. Ya, visi dan hasrat itu penting, tetapi karyawan harus memercayai Anda untuk merasa terinspirasi. Anggota tim atau karyawan Anda memandang seorang pemimpin yang mengatakan kebenaran, mencoba melakukan hal yang benar, menjalani kehidupan yang 'baik' dan melakukan yang terbaik. Integritas didasarkan pada keyakinan dan nilai-nilai yang membimbing seseorang, dan merupakan contoh penting dari kualitas kepemimpinan yang penting. Penting untuk mengetahui bahwa integritas (atau ketiadaannya) tercermin dalam pemikiran, sikap, dan tindakan. Orang tidak dapat secara langsung melihat tingkat integritas Anda, tetapi mereka menilainya dengan cukup akurat pada tingkat intuisi berdasarkan tindakan dan kata-kata Anda

\section{Directing}

Seorang pemimpin yang baik memberdayakan pengikut. Jika kemajuan ke arah pencapaian tujuan berhenti, pemimpin mengambil tanggung jawab untuk menganalisis masalah - dia tidak mencari orang untuk disalahkan. Jadi orang dapat memiliki keyakinan bahwa upaya mereka tidak akan dihukum jika mereka mengambil risiko yang masuk akal dan bertanggung jawab. Para pemimpin harus bisa menunjukkan kepada para pengikut apa yang akan mereka dapatkan dalam perjalanan bersama. Mereka berkomunikasi tidak hanya arah keseluruhan, tetapi informasi apa pun yang mungkin perlu pengikut dengan sukses dan terampil menjalankan tanggung jawab mereka

\section{Empaty}

Untuk mengalami inspirasi, orang juga perlu merasa dilibatkan dan dipahami. Inklusi melampaui pendengaran dan umpan balik; untuk inklusi nyata, orang perlu merasa terhubung erat dengan tindakan dan proses yang mengarah pada pencapaian tujuan atau 
keputusan (Daniel Goleman et al., 2003). Simpati adalah sine qua non dari semua efektivitas sosial dalam kehidupan kerja. Para pemimpin selalu membutuhkan empati untuk mengembangkan dan mempertahankan orang-orang yang baik, tetapi setiap kali ada bakat perang, taruhannya lebih tinggi.

\section{Strategy}

Para pemimpin memiliki strategi untuk mengatasi masalah dan bekerja ke arah visi mereka. Strateginya mungkin sederhana atau kompleks tetapi selalu melibatkan membuat asumsi tertentu tentang masa depan dan mengambil tindakan di masa kini untuk secara positif memengaruhi masa depan itu. Merencanakan berarti fokus lebih strategis. Rencana penting untuk bimbingan dan fokus, tetapi rencana jarang dapat dilempar menjadi batu. Pemimpin yang baik, selain menjaga tujuan utama tetap fokus, dapat berpikir analitis. Tidak hanya pemimpin yang baik memandang situasi secara keseluruhan, tetapi mereka juga dapat memecahnya menjadi sub-bagian untuk pemeriksaan lebih dekat dan merencanakan tindakan untuk kemajuan yang jelas. Mereka memiliki visi yang jelas, arah yang jelas dan pendekatan seperti laser untuk memotong hambatan. Pemimpin yang baik memiliki ide-ide baru dan mereka memanfaatkan orang, kebijakan, dan perencanaan untuk mencapai hasil. Mereka memiliki rencana untuk mencapai tujuan. Mereka tidak terjebak dengan detail (itulah gunanya manajer), tetapi mereka menggunakan rencana tingkat tinggi untuk membuat setiap orang bergerak bersama menuju tujuan. Sangat menarik untuk mengetahui bahwa inovasi adalah bagian terpenting dari strategi pemimpin yang baik

\section{Decition Making}

Pengambilan keputusan adalah kualitas utama dan berada di bagian bawah segitiga dalam model kepemimpinan karena pada akhirnya memupuk tindakan. Seorang pemimpin organisasi harus dapat mengarungi informasi, memahami apa yang relevan, membuat keputusan yang dipertimbangkan dengan baik, dan mengambil tindakan berdasarkan keputusan itu. Membuat keputusan terlalu cepat atau terlalu lambat akan menghambat efektivitas kepemimpinan Anda. Seorang pemimpin juga perlu berfungsi secara tertib dan terarah dalam situasi ketidakpastian. Orang-orang memandang pemimpin selama masa ketidakpastian dan ketidaktahuan dan menemukan jaminan dan keamanan ketika pemimpin menggambarkan kepercayaan diri dan sikap positif. Ketika orang menghormati satu 
sama lain, ada kepercayaan yang dibangun yang mengarah pada sinergi, saling ketergantungan dan rasa hormat yang mendalam. Kedua belah pihak membuat keputusan dan pilihan berdasarkan apa yang benar, apa yang terbaik dan apa yang paling dihargai.

\section{Influence and Developing}

Mengembangkan orang lain adalah peran penting bagi seorang pemimpin. Mendorong orang lain untuk memperluas kemampuan mereka dan mengambil tugas tambahan adalah bagian dari tanggung jawab pemimpin. Para pemimpin yang merasa terancam oleh kemampuan orang lain ditantang di bidang ini. Pembinaan dan pengembangan adalah keterampilan penting yang harus dipupuk oleh semua pemimpin. Jaringan, keterampilan hubungan yang baik, dan keterampilan komunikasi antarpribadi dan kelompok yang baik membantu para pemimpin yang baik untuk mengembangkan orang lain untuk mencapai lebih banyak tidak hanya untuk diri mereka sendiri tetapi juga untuk tim dan organisasi

\section{Positif mindset.}

Salah satu teknik yang paling membantu yang dapat digunakan pemimpin untuk menerapkan empat strategi kepemimpinan positif adalah teknik yang disebut sebagai program Personal Management Interview (PMI). Teknik ini berlaku dalam pengaturan profesional dengan pemimpin dan bawahan, dalam keluarga dengan orang tua dan anak-anak, dan dalam pengaturan sukarela seperti itu sebagai organisasi berbasis spiritual atau kelompok layanan masyarakat. Program PMI menyediakan cara langsung untuk melembagakan empat strategi positif secara berkelanjutan (Cameron, 2008, p. 81). Pemimpin positif memungkinkan kinerja luar biasa dengan menumbuhkan iklim kerja yang positif, memungkinkan kinerja luar biasa dengan membina hubungan positif di antara anggota, memungkinkan kinerja luar biasa dengan membina komunikasi positif, memungkinkan kinerja luar biasa dengan mengaitkan pekerjaan yang dilakukan dengan makna positif, serta memungkinkan kinerja yang luar biasa dengan menerapkan empat strategi ini melalui PMI program.

Lebih lanjut Cameron menyebutkan bahwa untuk mengembangkan positif ledership setidaknya ada dua langkah utama yang harus dilakukan, (1) mendiagnosis perilaku kepemimpinan saat ini, dan (2) mengidentifikasi tindakan spesifik yang membantu 
menerapkan empat strategi kepemimpinan positif (Cameron, 2008, pp. 104-105).

\section{Kesimpulan dan Implikasi}

Konsepsi kepemimpinan dalam konteks pendidikan berbeda dengan konsepsi kepemimpinan secara umum (general). Kepemimpinan pendidikan memiliki ciri khas tersendiri dibanding dengan kepemimpinan organisasi selainnya. Dalam rangka mencapai tujuan bersama, seorang pemimpin dituntut untuk mampu mengembangkan kemampuan shoft skillnya. Soft skill seorang pemimpin pendidikan berkaitan dengan karakter dan keterampilan interpersonal.

\section{Daftar Pustaka}

Abuddin Nata. (2012). Manajemen Pendidikan: Mengatasi Kelemahan Pendidikan Islam di Indonesia. Kencana.

Afshari Mostafa, Honari Habib, Qafouri Farzad, \& Jabari Nahid. (2012). Prioritizing Managerial Skills Based on Katz's Theory in Physical Education Offices of Universities in Iran. World Applied Sciences Journal, 20(3), 388-394.

Arifin, Z. (2016). Efektifitas Kepemimpinan Lembaga Pendidikan Islam di Pesantren. Jurnal Pemikiran Keislaman, 27(1). https://doi.org/10.33367/tribakti.v27i1.258

Cameron, K. (2008). Positive Leadership: Strategies for Extraordinary Performance. Berrett-Koehler Inc.

Daniel Goleman, Richard Boyatzis, \& Annie Mckee. (2003). Empathy: The Business Case. The Warner Books.

David R. Kolzow. (2014). Leading From Within: Building Organizational Leadership Capacity.

Gary Yukl. (1998). Leadership in Organization 3e (Jusuf Udaya, Trans.). Prenhallindo. 
Ghanem, B. O., \& Abu Awwad, F. M. (2019). The Degree of Principals' Practice of Leadership Skills from the Perspective of UNRWA School Teachers. International Education Studies, 12(7), 106. https://doi.org/10.5539/ies.v12n7p106

Hidayati, H. (2016). Kepemimpinan Dan Peningkatan Mutu Pendidikan. JURNAL TARBIYAH, 22(1). https://doi.org/10.30829/tar.v22i1.5

Hiebert, M., \& Klatt, B. (2001). The encyclopedia of leadership: A practical guide to popular leadership theories and techniques. McGraw-Hill.

Indah Kusuma Dewi. (2019). Implementasi Nilai-Nilai Profetik Dalam Kepemimpinan Modern Pada Manajemen Kinerja Di Perguruan Tinggi Islam Swasta Kota Metro [PhD, Pascasarjana Doctor]. http://repository.radenintan.ac.id

Muna, F. A., \& Zennie, Z. A. (2010). Developing multicultural leaders: The journey to leadership success. Palgrave Macmillan.

Nasution, W. N. (2016). Kepemimpinan Pendidikan Di Sekolah. JURNAL TARBIYAH, https://doi.org/10.30829/tar.v22i1.6

22(1).

Neff, T. J., Citrin, J. M., \& Brown, P. B. (2001). Lessons from the top: The 50 most successful business leaders in America--and what you can learn from them (1st Currency pbk. ed). Currency/Doubleday.

Robbins, S. P. (2001). Organizational behavior (9. ed). Prentice Hall.

Romy Faisal Mustofa, R., Duran Corebima, A., Endang Suarsini, E., \& Saptasari, M. (2019). The Correlation between Generic Skills and Metacognitive Skills of Biology Education Students in Tasikmalaya Indonesia Through Problem-Based Learning Model. The Journal of Social Sciences Research, 54, 951-956. https://doi.org/10.32861/jssr.54.951.956 
Seyedinejat, S., Razaghi, M., \& Dousti, M. (2014). Prioritizing Managerial Skills Based on Katz's Theory Cast study: The managers of Sports and Youth in Mazandaran Province. Pamukkale Spor Bilimleri Dergisi, 5(1), 33-47.

Sutarto. (2006). Dasar-dasar kepemimpinan administrasi. Gadjah Mada University Press.

Syadzili, M. F. R. (2018). Model Kepemimpinan dan Pengembangan Potensi Pemimpin Pendidikan Islam. CENDEKIA: Jurnal Studi Keislaman, 4(2), 127-136. https://doi.org/10.37348/cendekia.v4i2.54

Wirawan. (2014). Kepemimpinan: Teori, Psikologi, Prilaku Organisasi, Aplikasi dan Penelitian (2nd ed.). PT Rajagrafindo Persada. 